\title{
Scandix pecten-veneris L. (Apiaceae) in the Małopolska Upland (S Poland) - regional changes in the distribution and population resources of declining weed species
}

\section{Grzegorz Łazarski}

Department of Plant Taxonomy, Phytogeography and Herbarium, Institute of Botany, Jagiellonian University, Kopernika 27, 31-501 Kraków, Poland, e-mail: grzegorz.lazarski@gmail.com

\begin{abstract}
The paper presents results of the inventory of localities of Scandix pecten-veneris L. in the Małopolska Upland conducted after 2000. The existing population resources were estimated and current distribution of the species in the Małopolska Upland and Poland was showed. Some threats to this species as well as conservation prospects were discussed.
\end{abstract}

Key words: Scandix pecten-veneris, endangered weed species, distribution, population resources, archaeophytes, the Małopolska Upland, Poland

\section{Introduction}

Scandix pecten-veneris L. has a status of an archaeophyte in Polish flora. It is a plant of MediterraneanIrano-Turanian origin (Zając 1987) which, as a weed, spread its range, among others, to Central Europe. Meusel et al. (1965) classed it as a Mediterranean-IranoTuranian-Central-European connecting element. Parts of the eastern and northern limit of its secondary range are placed in Poland (Hultén \& Fries 1986; Zając et al. 2014).

The species was recorded mainly in southern part of Poland - in the Małopolska, Lublin and SilesianKraków Uplands. Solitary localities from north and north-west Poland are considered as historical (Zając et al. 2014). The largest numbers of the Polish localities of the species come from the Małopolska Upland. They are concentrated in center (limestone part of the Świętokrzyskie Mountains and the PrzedbórzMałogoszcz Range) and south (the Nida Basin) of the Upland. Most of known localities from the southern part of the Małopolska Upland were recorded in 1950s and 1960s. These data were the result of intensive studies conducted by botanists from the neighbouring Kraków research center. In 1970s and 1980s, several papers were published on synanthropic (principally segetal) flora of central part of the Małopolska Upland - in broadly understood Kielce region (Wnuk 1972, 1978; Fijałkowski \& Cieśliński 1975; Dominiak \& Moćko 1980; Głazek et al. 1986-1987; Maciejczak 1988). Fourteen localities of S. pecten-veneris were listed by Wnuk $(1972,1978)$ in the Przedbórz-Małogoszcz Range. Dominiak \& Moćko (1980) reported its occurrence in the Świętokrzyskie Mountains. Głazek et al. (1986-1987) investigated distribution of selected species of segetal weeds in Kielce and Tarnobrzeg regions. According to them, S. pectenveneris was a frequent (!) archeophyte with 97 localities in the area of study. These authors indicated Pińczów Hummock, Szydłów Foothill and south, limestone part of the Świętokrzyskie Mountains as areas with the highest density of its stations. More recent studies (Nobis et al. 2007) carried out in the southern part of the Małopolska Upland (Nida Basin) showed that a vast majority of those localities became extinct (only several were confirmed).

S. pecten-veneris, as other segetal species from the Caucalido-Scandicetum association, has been in decline recently. Populations observed after 1980s are small, usually consisting of several individuals. The species decreased as a result of modern agricultural methods 
(mainly herbicide treatments and seed screening). For all these reasons, S. pecten-veneris was placed in the Polish "Red Book" and "Red List" of archaeophytes as a critically endangered - CR category (Zając et al. 2009, 2014) and "Red List" of all regions of Poland where it occurred. In the area of Western Pomerania and Wielkopolska (Żukowski \& Jackowiak 1995; Jackowiak et al. 2007), Gdańsk Pomerania (Markowski \& Buliński 2004), Lower Silesia (Anioł-Kwiatkowska \& Popiel 2011), it was found to be extinct (EX category). In Lublin region (Kucharczyk \& Wójciak 1995), the Małopolska Upland (Bróż \& Przemyski 2009) and the territory of Silesian Voivodeship (Parusel \& Urbisz 2012), the species was included in the category of endangered (EN) plants.

S. pecten-veneris occurs on alkaline soils (mainly rendzinas) formed on limestone or rarely gypsum. It grows in cereal cultivations (in a rare CaucalidoScandicetum association, where it is a character species) and, sporadically, in root crop cultivations (in LamioVeronicetum politae) (Matuszkiewicz 2006).

This work shows the results of analyses of the existing population resources and current distribution of S. pecten-veneris in the Małopolska Upland. The previously known localities from the Małopolska Upland, both confirmed and not evidenced, as well as newly found during the field research are presented. These results are a contribution to the research that should be conducted also in other regions to gain a comprehensive knowledge of the distribution and population resources of $S$. pecten-veneris in Central Europe in times of widespread weed extinction.

\section{Material and methods}

The field inventory of $S$. pecten-veneris population was made during a general phytogeographical study which was conducted in the central part of the Małopolska Upland: in the Świętokrzyskie Mountains (in 2010-2014), in the SE edge of Przebórz-Małogoszcz Range (2008-2010). Floristic data were collected in plots - squares of $2.5 \mathrm{~km}$ side, which were determined on the basis of the ATPOL grid system (Zając 1978). Locations of the registered stations were set using a GPS receiver. Units of regionalization of Poland follow Kondracki (2002). At each locality, the population size was estimated by counting flowering or fruiting individuals.

Localities of S. pecten-veneris known from literature were selected and located in the ATPOL grid system units (squares of $2.5 \mathrm{~km}$ side), if possible. The herbarium collections of the species were also taken into account.

Table 1. Localities of Scandix pecten-veneris L. in the Małopolska Upland discovered or confirmed after 2000

\begin{tabular}{|c|c|c|c|c|c|c|}
\hline No. & $\begin{array}{l}\text { ATPOL } \\
\text { square }\end{array}$ & Locality & $\begin{array}{l}\text { Geographical } \\
\text { coordinates }\end{array}$ & Literature & Pop. size & Habitat \\
\hline \multicolumn{7}{|c|}{ Świętokrzyskie Mts } \\
\hline $1 !$ & EE7233 & $\begin{array}{l}\text { S of the central part of Gałęzice v. } \\
\text { (near the Ostrówka quarry) }\end{array}$ & $\begin{array}{l}50^{\circ} 50^{\prime} 29.5^{\prime \prime} \mathrm{N} \\
20^{\circ} 24^{\prime} 44.7 " \mathrm{E}\end{array}$ & - & $\mathrm{D}$ & $\begin{array}{l}\text { cult. of barley on } \\
\text { d. rendzinas }\end{array}$ \\
\hline $2 !$ & EE8201 & $\begin{array}{l}\text { NE of the NW edge of Milechowy } \\
\text { v. (SW slope of Grząby Bolmińskie } \\
\text { range) }\end{array}$ & $\begin{array}{l}50^{\circ} 49^{\prime} 33.5^{\prime \prime} \mathrm{N} \\
20^{\circ} 19^{\prime} 54.0^{\prime \prime} \mathrm{E}\end{array}$ & - & $\mathrm{C}$ & $\begin{array}{l}\text { cult. of barley on } \\
\text { j. rendzinas }\end{array}$ \\
\hline 3 & EE8202 & $\begin{array}{l}\text { NE of the central part of Bolmin v. } \\
\text { (SW slope of Grząby Bolmińskie } \\
\text { range) }\end{array}$ & $\begin{array}{l}50^{\circ} 48^{\prime} 59.4^{\prime \prime} \mathrm{N} \\
20^{\circ} 21^{\prime} 05.9^{\prime \prime} \mathrm{E}\end{array}$ & $\begin{array}{l}\text { registered also } \\
\text { by Dominiak \& } \\
\text { Moćko } 1980\end{array}$ & $\begin{array}{l}\mathrm{A} \text { in } \\
2012 ; \mathrm{B} \\
\text { in } 2014\end{array}$ & $\begin{array}{l}\text { cult. of wheat on } \\
\text { j. rendzinas }\end{array}$ \\
\hline \multicolumn{7}{|c|}{ Nida Basin } \\
\hline $4 \& 5$ & $\begin{array}{l}\text { EF1302 } \\
\& \text { EF1303 }\end{array}$ & $\begin{array}{l}\text { b. Skowronno reserve and a closed } \\
\text { dairy in Pińczów, at the foot of the } \\
\text { S slopes of Pińczów Mts }\end{array}$ & - & $\begin{array}{l}\text { Nobis et al. } \\
2007\end{array}$ & $\mathrm{~B}$ & $\begin{array}{l}\text { fields and fallows } \\
\text { adjacent to } \\
\text { grasslands, at the }\end{array}$ \\
\hline $6 \& 7$ & $\begin{array}{l}\text { EF1420 } \\
\& \text { EF1421 }\end{array}$ & $\begin{array}{l}\text { E of Pińczów (b. Pińczów and } \\
\text { Bogucice v.), at the foot of S slopes } \\
\text { of Pińczów Mts }\end{array}$ & - & $\begin{array}{l}\text { Nobis et al. } \\
2007\end{array}$ & $\mathrm{~B}$ & $\begin{array}{l}\text { foot of S slopes } \\
\text { of hills }\end{array}$ \\
\hline 8 & EF2400 & $\begin{array}{l}\text { n. Krzyżanowice reserve, from } \\
\text { the side of the road connecting the } \\
\text { Gacki and Krzyżanowice v. }\end{array}$ & - & $\begin{array}{l}\text { Nobis et al. } \\
2007\end{array}$ & A & $\begin{array}{l}\text { fields at the foot } \\
\text { of a steep hill }\end{array}$ \\
\hline $9 \& 10$ & $\begin{array}{l}\text { EF2401 } \\
\& \text { EF2412 }\end{array}$ & n. Wola Zagojska Dolna & - & $\begin{array}{l}\text { Nobis et al. } \\
2007\end{array}$ & $\mathrm{D}$ & $\begin{array}{l}\text { fields at the foot } \\
\text { of a gypseous hill }\end{array}$ \\
\hline
\end{tabular}

Explanations: classes of estimated population size, A - 1-10, B - 11-50, C - 51-100, D - >100; population of plants growing close to each other, but in the different units of 2,5 x 2,5 km cartogram, were considered as separate localities (according to the cartogram method); cult. - cultivation, v. - village, n. - near, b. - between, j. - Jurassic, d. - Devonian, ! - newly discovered localities, Pop. - Population 


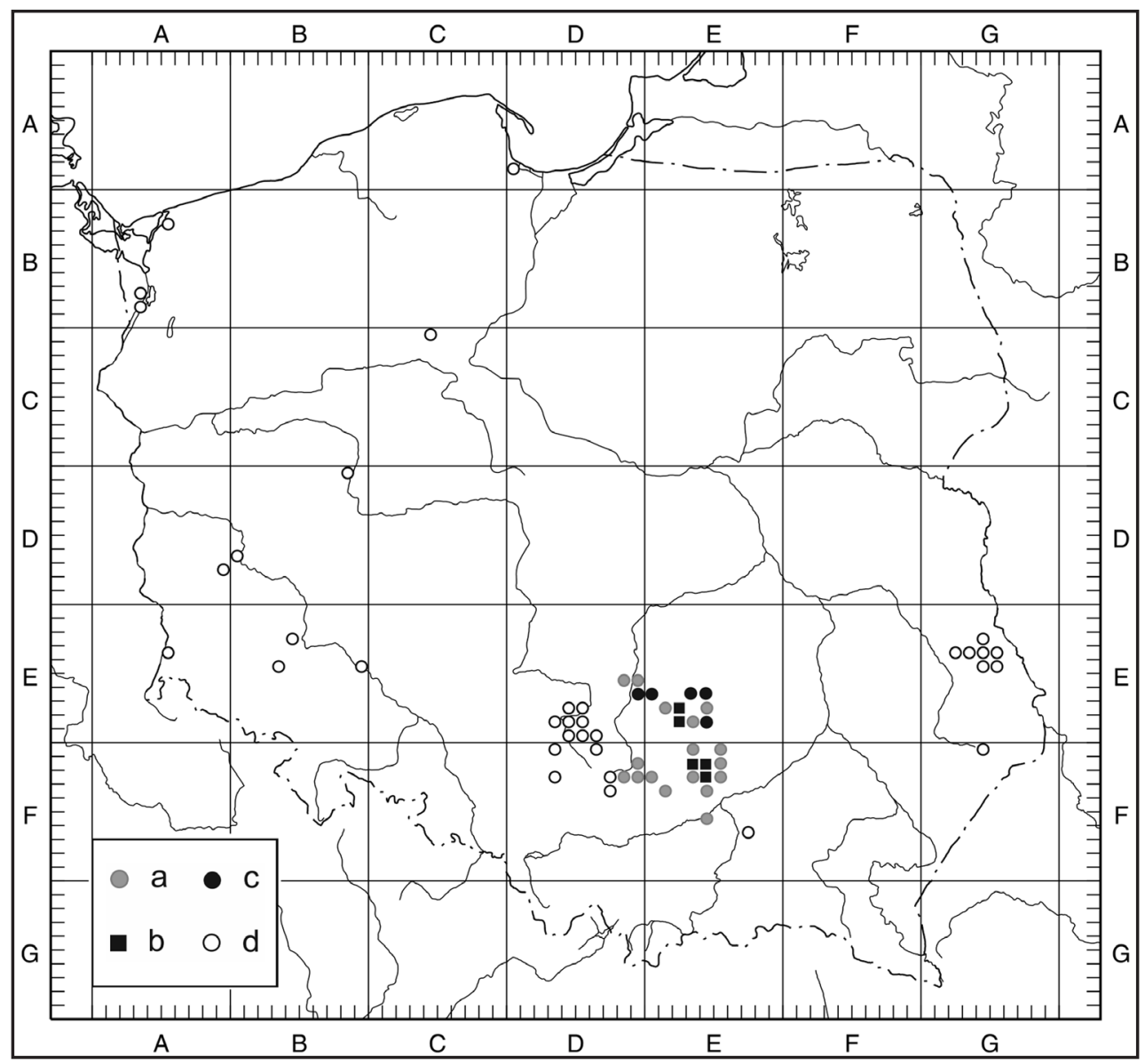

Fig. 1. Distribution of Scandix pecten-veneris L. in Poland (Zając \& Zajac 2001, modified)

Explanations: a - published and unpublished localities from the Małopolska Upland, $\mathrm{b}$ - localities confirmed after 2000, $\mathrm{c}$ - published localities from the Małopolska Upland, which weren't included in the ATPOL database, $d$ - published and unpublished localities from other parts of Poland

Finally, a list of localities of S. pecten-veneris was created on the basis of: data collected by the author during field studies, published information, unpublished data gathered in ATPOL database and accessible herbarium collections. Imprecise data from the article of Głazek et al. (1986-1987), presented in the form of large-scale map with plotted localities of the species (without the list of localities), was left out of this list.

Distribution of the species in the Małopolska Upland was presented on the map with ATPOL grid in cartogram

Table 2. Localities of Scandix pecten-veneris L. in the Małopolska Upland, found in the literature but not included in the ATPOL database

\begin{tabular}{|c|c|c|c|c|}
\hline No & $\begin{array}{l}\text { ATPOL } \\
\text { square }\end{array}$ & Locality & Literature & Habitat \\
\hline 1 & DE6900 & Kolonia Łapczyna Wola & \multirow[t]{5}{*}{ Wnuk 1978} & \multirow{5}{*}{$\begin{array}{l}\text { weedy cult. of wheat } \\
\text { and barley on mixed } \\
\text { j. and c. rendzinas }\end{array}$} \\
\hline 2 & DE6901 & Dobromierz & & \\
\hline 3 & DE6901 & Kowale & & \\
\hline 4 & DE6903 & Stara Wieś & & \\
\hline 5 & EE6032 & Wola Świdzińska & & \\
\hline 6 & EE6032 & Świdno & Wnuk 1972 & arable cult. \\
\hline 7 & EE6333 & b. Laskowa and Kostomłoty Drugie & Bróż \& Maciejczak 1991 & $\begin{array}{l}\text { arable cult. on d. } \\
\text { rendzinas }\end{array}$ \\
\hline 8 & EE6430 & Kostomłoty & Dominiak \& Moćko 1980 & $\begin{array}{l}\text { arable cult. on } \\
\text { rendzinas }\end{array}$ \\
\hline 9 & EE8400 & N of Kowala Duża & \multirow[t]{2}{*}{ Bróż \& Maciejczak 1991} & \multirow{2}{*}{$\begin{array}{l}\text { arable cult. on d. } \\
\text { rendzinas }\end{array}$} \\
\hline 10 & EE8410 & S of Kowala Duża & & \\
\hline
\end{tabular}

Explanations: cult. - cultivation, b. - between, j. - Jurassic, c. - Cretaceous, d. - Devonian 


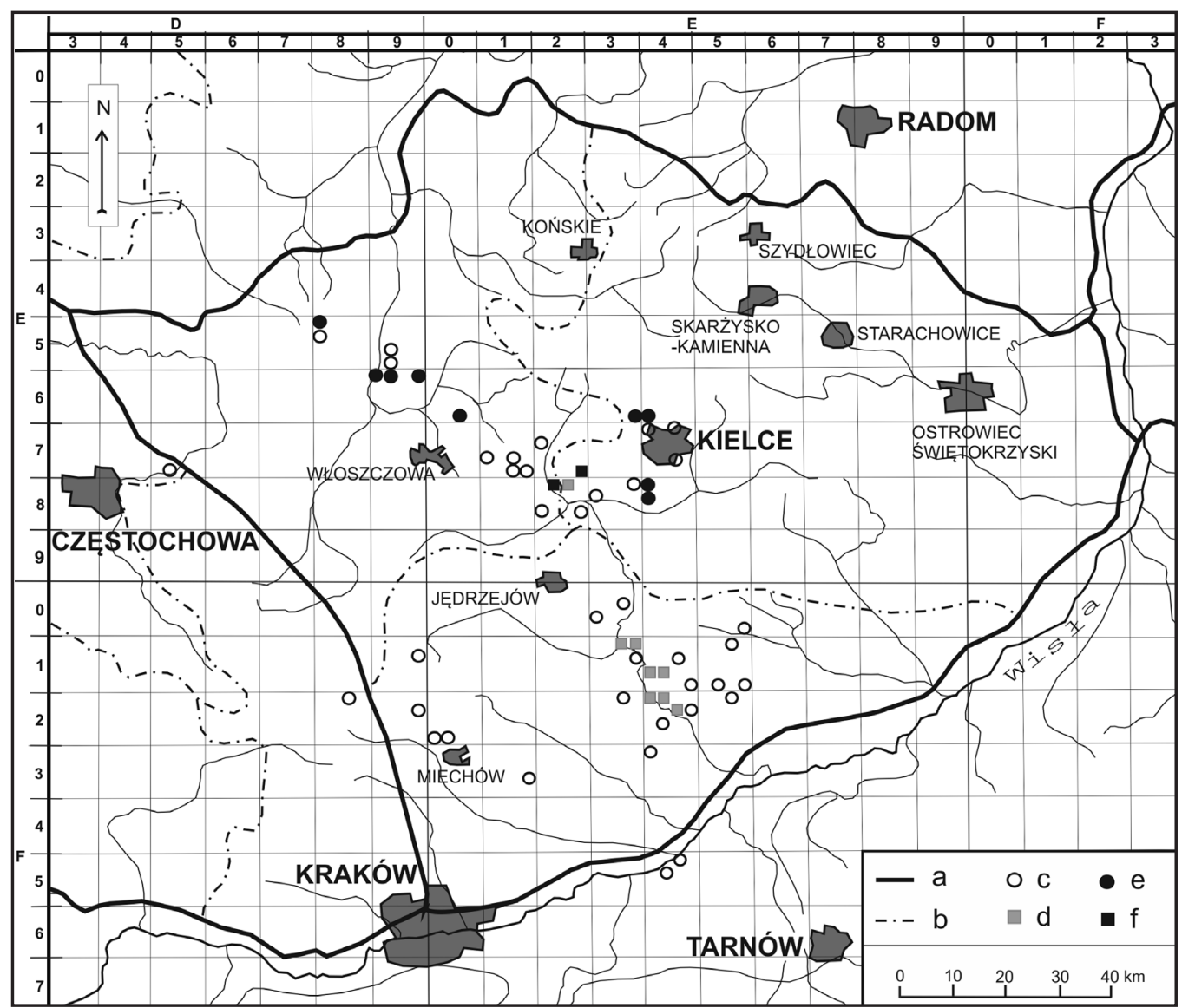

Fig. 2. Distribution of Scandix pecten-veneris L. in the Małopolska Upland

Explanations: $\mathrm{a}$ - border of the Małopolska Upland, $\mathrm{b}$ - border of the macroregions, $\mathrm{c}$ - localities published or unpublished, $\mathrm{d}$ - localities confirmed after $2000, \mathrm{e}$ - published localities, which weren't included in the ATPOL database, $\mathrm{f}-$ a newly discovered locality

of $2.5 \mathrm{~km}$ side, and in Poland - of $10 \mathrm{~km}$ side. In the ATPOL grid system, capital letters designate $100-\mathrm{km}$ squares and the first two digits indicate $10-\mathrm{km}$ squares and two further ones -2.5-km squares (Zając 1978).

\section{Results}

On the basis of the collected data, a list of localities of $S$. pecten-veneris (Appendix 1) in the area of the Małopolska Upland was drawn up. As available literature indicates, the species was listed in over 60 stations located in 57 cartogram units of $2.5 \mathrm{~km}$ side in the Małopolska Upland. Only 10 of them were confirmed during field research conducted after 2000 (Table 1). Moreover, there were two new localities found in 2014.

Based on the available data, distribution maps of $S$. pecten-veneris in Poland (Fig. 1) and in the Małopolska Upland (Fig. 2) were prepared and distinction was made between historical and currently occurring localities. Updated maps also contain published data, which was not listed in the ATPOL database (Table 2).

The observed populations usually ranged from a few to several individuals. However, in localities near the villages of Wola Zagojska Dolna (Nida Basin) and Gałęzice (the Świętokrzyskie Mts.), the species grew abundantly (populations consisted of several hundred individuals).

\section{Discussion}

Results support earlier observations that Polish localities of $S$. pecten-veneris are concentrated in the Małopolska Upland. Considering that the published data on the species was not confirmed in Lublin region during research in 2005-2010 (Haliniarz \& Kapeluszny 2014), in Gdańsk Pomerania (Markowski \& Buliński 2004) and Western Pomerania and Greater Poland (Żukowski \& Jackowiak 1995; Jackowiak et al. 2007), reports of new localities in the Małopolska Upland are all the more important. The Świętokrzyskie Mts. and Nida Basin are the only subregions in the Małopolska Upland, where $S$. pecten-veneris localities were confirmed after 2000 . The species was not reported from the area of south-eastern part of the Przedbórz-Małogoszcz Range (Lazarski 2011). Localities based on literature data (Wnuk 1972, 1978) in the rest of this area need confirmation. 


\subsection{Reasons of decrease}

Rare weed species are currently under pressure due to changes in arable management practices (Peters \& Gerowitt 2014). Out of more than 165 of all archaeophytes in Poland, 74 are classifies as extinct or endangered (Zając et al. 2009). In modern times, first changes in the frequency of segetal species occurred with the introduction of mineral fertilizers and mechanized management (Holzner \& Immonen 1982) followed by the adoption of widespread herbicide use (Baessler \& Klotz 2006; Peters \& Gerowitt 2014). Introduction to cultivation of new, more competitive, high-yielding varieties of cereals also became a serious threat to rare archaeophytes. High-yielding crops in conjunction with the use of mineral fertilizers caused greater crop densities which, afterwards, affected the increase of shadow in lower cultivation layers (Wilson 2006). This resulted in species of poor competitors for light, such as S. pecten-veneris, to disappear from habitat. In experimental studies, species richness and weed growth were significantly reduced in the fertilized cultivation, which was associated with restricted light penetration (Kleijn \& van der Voort 1997). All these factors led to uniformity of land use hazardous for biodiversity.

Recently, attention is drawn to consequences of climate change for frequency of occurrence of rare arable weed species. Experimental research showed that negative effects of the use of modern agricultural practices on segetal weed species can be more intensive in conjunction with climate changes. Under warmer and dryer conditions, S. pecten-veneris flowered earlier and for shorter time and, finally, produced fewer shoots and seeds at harvesting time (lower generative production). These changes in climatic conditions are neutral or even advantageous for weeds species, but only under nutrient-poor soil (so not under current agricultures practices). Nowadays, agricultural management provides no limiting nutrient conditions in which $S$. pecten-veneris is low competitive (retained nutrients provide no advantage). Similar effects are caused by a high density of crops (which is a result of fertilization and sowing high-yielding varieties of cereals). Seed output of the $S$. pecten-veneris is lower in dense crops. Probably, it is the result of increased shading caused by high crop density (Peters \& Gerowitt 2014); moreover, $S$. pecten-veneris requires large gaps in vegetation for seedling formation (Wilson 2006).

It is considered that most rare weed species exhibit specific trait syndromes. Among these traits, S. pectenveneris has, for example, low height, poor competitive ability, large seeds, poor seed dispersal, easy seed cleaning, relatively short-lived seed-bank (Storkey 2006; Wilson 2006; Lososová et al. 2008). Most of these traits are disadvantageous under conditions created by modern agricultural practices. Earier-mentioned life history traits of S. pecten-veneris reflect its low phenotypic plasticity (Peters \& Gerowitt 2014).

\subsection{Conservation prospects}

The best chance to save or regenerate weed fields with their "natural" combination of species is to establish areas (maybe, as agricultural reserves or within protected areas whose aim could be to take care of the preservation of landscape specificity) where traditional, extensive cultivation would be carried out. At the same time, in areas with endangered weed species, a system of subsidies to farmers for maintaining traditional methods of cultivation should be implemented (Nobis et al. 2007). Additionally, rare weeds should be grown, for example, in open-air museums, botanical gardens and other research institutions. They could be a resource of specimens for introduction into substitute habitats (Zając \& Zając 2014). Diaspores of species, collected in different regions, should be deposited in seed banks.

Moreover, to assist protection of rare weed species, it is important to apply herbicides that are highly specific to aggressive weed species and to create unsprayed conservation headlands and field margins. Conservation of headlands and field margins could be a method of providing a refuge for endangered arable weeds (de Snoo 1994; Kleijn \& van der Voort 1997).

\section{Conclusions}

S. pecten-veneris still remains in the Małopolska Upland mainly in small, declining populations. From among about 60 localities of this species published up to 2000 , only about $15 \%$ were confirmed in this study. Only populations in Gałęzice and Wola Zagojska Dolna villages were numerous with more than one hundred individuals. Others contained a dozen or so specimens (in Milechowy village) and most of them with few individuals. While agriculture in Poland underwent a deep process of modernization, the risk of extinction of S. pecten-veneris is high and its gradual disappearance from arable fields is probably inescapable.

Because of high specialization, $S$. pecten-veneris is restricted to Caucalido-Scandicetum association. This weed species is competitive only under nutrient-poor, calcareous soils and in crops of low density. Due to its low phenotypic plasticity, the species is less buffered against changes which take place in agricultural practices (Fried et al. 2010; Peters \& Gerowitt 2014). In order to save $S$. pecten-veneris, apart from promotion of traditional cultivation methods on calcareous soils in selected areas, it is also necessary to start ex situ cultivation and gather diaspores in seed banks. Conservation of headlands and field margins may provide a refuge for endangered segetal weeds. 
Acknowledgements. I wish to thank Prof. Maria Zając for her helpful comments on the manuscript and providing me the localities of Scandix pecten-veneris from the ATPOL data base. I am also grateful to Agata Maćkowiak for her linguistic support during preparation of the manuscript.

\section{References}

Aniol-Kwiatkowska J. \& Popiel A. 2011. Scandix pecten-veneris (Apiaceae) - historia występowania na Dolnym Śląsku. In: J. AnioŁ-Kwiatkowska \& E. Szczę́śniak (eds.). Zagrożone archeofity Dolnego Śląska. Acta Bot. Siles., Suppl. 1: 192-194.

BAessler C. \& Klotz S. 2006. Effects of changes in agricultural land-use on landscape structure and arable weed vegetation over the last 50 years. Agric. Ecosyst. Environ. 115: 43-50.

Bróż E. \& MaciejczaK B. 1991. Some new, rare and endangered species of vascular plants of Kielce and its suburb. Fragm. Flor. Geobot. 36(1): 171-179.

Bróż E. \& PrZEMYSKi A. 2009. The red list of vascular plants in the Wyżyna Małopolska upland (S Poland). In: Z. Mirek \& A. Nikiel (eds.). Rare, relict and endangered plants and fungi in Poland, pp. 123-136. W. Szafer Institute of Botany, Polish Academy of Sciences, Kraków.

Dominiak B. \& MoćKo E. 1980. Interesujące gatunki segetalne mezoregionu Góry Świętokrzyskie. Studia Kieleckie 3(27): 33-35.

FiJAŁKowski D. \& CieŚLiński S. 1975. Rzadsze rośliny synantropijne Kielecczyzny jako wskaźniki siedliskowe. Studia Kieleckie 4(8): 5-20.

Fried G., Petit S. \& Reboud X. 2010. A specialist-generalist classification of the arable flora and its response to changes in agricultural practices. BioMed Cent. Ecol. 10(20): 1-11.

GŁazek T. 1984. Rezerwat stepowy Góry Pińczowskie w województwie kieleckim. Chrońmy Przyr. Ojcz. 40(5-6): 5-13.

GŁazek T., Kowalik E., ŁuszczyŃsKa B. \& Łuszczyński J. 1986-1987. Distribution of selected species of segetal weeds belonging to the Caucalidion daucoidis $\mathrm{R}$. Tx. 1950 alliance on the area of the Kielce province and the western part of the Tarnobrzeg province (the Central Little Poland Highland subprovince). Fragm. Flor. Geobot. 31-32(1-2): 121-140.

Haliniarz M. \& Kapeluszny J. 2014. Rzadkie gatunki flory kalcyfilnej w zbiorowiskach segetalnych na terenie województwa lubelskiego. Annales Universitatis Mariae Curie-Skłodowska Lublin-Polonia. Sec. E. 69(1): 11-23.

Holzner W. \& Immonen R. 1982. The agrestal weed flora and vegetation of the world. In: W. Holzner \& M. Numata (eds.). Biology and ecology of weeds, pp. 203-226. The Hague, Boston.

Hultén E. \& Fries M. 1986. Atlas of North European vascular plants. North of the Tropic of Cancer. I-III. xvi+1172 pp. Koeltz Scientific Books, Königstein.
Jackowiak B., Celka Z., Chmiel J., Latowski K. \& Żukowski W. 2007. Red list of vascular flora of Wielkopolska (Poland). Biodiv. Res. Conserv. 5-8: 95-127.

Kleijn D. \& van der Voort L. A. C. 1997. Conservation headlands for rare arable weeds: the effects of fertilizer application and light penetration on plant growth. Biological Conservation 81: 57-67.

Kondracki J. 2002. Geografia regionalna Polski. Wyd. 3. 441 pp. Wyd. Nauk. PWN, Warszawa.

Kostrowicki S. A. 1966. Stosunki biogeograficzne. In: J. Kondracki (red.). Studia geograficzne w powiecie pińczowskim. Przegl. Geogr. 47: 115-163.

KuCHARCZYK M. \& WóJCiAK J. 1995. Ginące i zagrożone gatunki roślin naczyniowych Wyżyny Lubelskiej, Roztocza, Wołynia Zachodniego i Polesia Lubelskiego. Ochrona Przyrody 52: 33-46.

Lososová Z., ChytrÝ M. \& Kühn I. 2008. Plant attributes determining the regional abundance of weeds on central European arable land. J. Biogeogr. 35: 177-187.

ŁAZARSKI G. 2011. Rare and endangered species of vascular plants in the valley of the Biała Nida river near Małogoszcz (the central part of Małopolska Upland). Fragm. Flor. Geobot. Polonica 18(2): 257-264.

MACIEJCZAK B. 1988. Flora synantropijna Kielc, SkarżyskaKamiennej i Starachowic. 162 pp. KTN, Kielce.

Markowski R. \& Buliński M. 2004. Ginące i zagrożone rośliny naczyniowe Pomorza Gdańskiego. Acta Botanica Cassub. Monogr. 1: 1-75.

Matuszkiewicz W. 2006. Przewodnik do oznaczania zbiorowisk roślinnych Polski. In: J. B. FALIŃSKi (ed.). Vademecum Geobotanicum 3, 537 pp. Wyd. Nauk. PWN, Warszawa.

Meusel H., JÄger E. \& Weinert E. 1965. Vergleichende Chorologie der zentraleuropäischen Flora. I. Text 583 pp., Karten 258 pp. Gustav Fischer Verlag, Jena.

Nobis M., Nobis A., Kozak M. \& Przemyski A. 2007. Occurrence of Conringia orientalis (Brassicaceae) and Scandix pecten-veneris (Apiaceae) in the area of Nida Trough. Fragm. Flor. Geobot. Polonica 14(1): 49-59.

Parusel J. B. \& Urbisz A. (eds.). 2012. Czerwona lista roślin naczyniowych województwa śląskiego. Raporty Opinie 6(1): 105-177.

Peters K. \& Gerowitt B. 2014. Response of the two arable weed species Lithospermum arvense and Scandix pecten-veneris to climate change conditions. Plant Ecol. 215: 1013-1023.

DE SNOO G. R. 1994. Cost-benefits of unsprayed crop edges in winter wheat, sugar beet and potatoes. In: N. BoATMAN (ed.). Field margins: integrating agriculture and conservation. BCPC Monogr. 58, pp. 197-202. 
SowA R. \& WARCholińska A. U. 1979. Flora segetalna Wzgórz Radomszczańskich. Acta Univ. Lodz. Ser. 2. 27: 75-119.

Storkey J. 2006. A functional group approach to the management of UK arable weeds to support biological diversity. Weed. Res. 46: 513-522.

SzWAGRZYK J. 1987. Flora naczyniowa Niecki Nidziańskiej. In: A. S. KLeCZKowski (ed.). Wartości środowiska przyrodniczego Niecki Nidziańskiej i zagadnienia jego ochrony. Część 2. Studia Ośrodka Dokumentacji Fizjograficznej 15: 17-91.

Wilson P. 2006. UK Biodiversity Action Plan for Scandix pecten-veneris. Plantlife International, The Wild Plant Conservation Charity. http://www.plantlife.org.uk/ uploads/documents/Scandix_pecten-veneris_dossier. pdf. Accessed 14 Jan 2015.

WNuk Z. 1972. Rzadsze chwasty segetalne Pasma Przedborsko-Małogoskiego i przyległych obszarów. Zesz. Nauk. Uniw. Łódzkiego. Ser. 2. 51: 181-186.

Wnuk Z. 1978. Flora segetalna Pasma PrzedborskoMałogoskiego i przyległych terenów. Acta Univ. Lodz. Ser. II, 20: 183-255.

WNUK Z. 1981. Niektóre nowe i rzadkie gatunki we florze segetalnej Wyżyny Częstochowskiej. Acta Univ. Lodz. Folia Bot. 1: 181-205.

ZajĄC A. 1978. Założenia metodyczne "Atlasu rozmieszczenia roślin naczyniowych w Polsce". Wiad. Bot. 22(3): 145-155.
ZAJAcC A. 1987. Studies on the origin of archaeophytes in Poland. Part III. Taxa of Irano-Turanian, Euro-SiberianIrano-Turanian and Mediterranean-Irano-Turanian origin. Zeszyty Nauk. Uniw. Jagiell. 834, Prace bot. 15: 93-129.

ZająC A. \& ZająC M. (eds.). 2001. Distribution Atlas of Vascular Plants in Poland. xii+714 pp. Edited by Laboratory of Computer Chorology, Institute of Botany, Jagiellonian University, Cracow.

Zając M., Urbisz A., Nobis M., Nobis A. 2014. CR Scandix pecten-veneris L. - czechrzyca (trybulka) grzebieniowa. In: R. KaźmierCZAKOwA, K. ZARZYCKi \& Z. MireK (red.). Polska czerwona księga roślin. Paprotniki i rośliny naczyniowe, wyd. 3, pp. 350-352. Instytut Ochrony Przyrody PAN, Kraków.

Zając M., Zajac A. \& ToKarska-GuZiK 2009. Extinct and endangered archaeophytes and the dynamics of their diversity in Poland. Biodiv. Res. Conserv. 13: 17-24.

ZAJĄC M. \& ZAJĄC A. 2014. Survival problems of archaeophytes in the Polish flora. Biodiv. Res. Conserv. 35: 47-56.

ŻUKOwsKi W. \& JACKOWIAK B. 1995. List of endangered and threatened vascular plants in Western Pomerania and Wielkopolska (Great Poland). In: W. Żukowski \& B. JACKOWIAK (eds.). Endangered and threatened vascular plants of Western Pomerania and Wielkopolska. Publications of the Department of Plant Taxonomy of the Adam Mickiewicz University in Poznań 3: 9-96. Bogucki Wyd. Nauk., Poznań. 


\section{Appendix 1. List of localities of Scandix pecten-veneris in the Małopolska Upland}

Explanations: leg. - collected by, n. - near, v. - village, not publ. - data not published in the ATPOL data base, GŚ - Góry Świętokrzyskie (Świętokrzyskie Mts.), NN - Niecka Nidziańska (Nida Basin), OB - on the border between Małopolska Upland and Częstochowa Upland, PPM - Pasmo Przedborsko-Małogoskie (Przedbórz-Małogoszcz Range), WR - Wzgórza Radomszczańskie (Radomsko Hills), ? - used by Nobis et al. (2007) - after the number of cartogram unit denotes an uncertain location of the species locality in the ATPOL grid system $(2,5 \times 2,5 \mathrm{~km})$, but after the name of the village/town it is an uncertain location of a locality, resulting from an imprecise distribution map created by Głazek et al. (1986-1987), ?? - uncertain location of a species locality in the ATPOL grid system $(2,5 \times 2,5 \mathrm{~km})$

WR: 1. DE5800 - Granice (Sowa \& Warcholińska 1979); 2. DE5810 - Chełmo (Sowa \& Warcholińska 1979; Wnuk 1978; Sowa \& Warcholińska 1978 not publ.); PPM: 3. DE5921 - Wymysłów (Wnuk 1972); 4. DE5931 - Rączki (Wnuk 1972); 5. DE6900 - Kolonia Łapczyna Wola (Wnuk 1978); 6. DE6901 - Dobromierz (Wnuk 1978); 7. DE6901 - Kowale (Wnuk 1978); 8. DE6903 - Stara Wieś (Wnuk 1978); 9. EE6032 - Świdno (Wnuk 1972); 10. EE6032 - Wola Świdzińska (Wnuk 1978); 11. EE7120 - Gruszczyn (Wnuk 1972); 12. EE7122 Bukowa Mt. (Wnuk 1978); 13. EE7132 - Cieśle (Wnuk 1978); 14. EE7132 - Kościółek Mt. (Wnuk 1978); 15. EE7133 - Leśnica (Wnuk 1978); 16. EE8220 - Karsznice (Wnuk 1978); GŚ: 17. EE6333 - between Laskowa and Kostomłoty Drugie (Bróż \& Maciejczak 1991 ); 18. EE6430 - Kostomłoty (Dominiak \& Moćko 1980); 19. EE7210 - Ruda (=Ruda Zajączkowska), Piekutowska 1979 not publ. 20. EE7233 $\mathrm{S}$ of the central part of Gałęzice v. (n. the Ostrówka quarry), 5050'29.5"N; 20²4'44.7"E; 21. EE7400 - Kielce, Kruszelnickiego "Wilka" Str. (Maciejczak 1988); 22. EE7400 - Niewachlów (Dominiak \& Moćko 1980); 23. EE7402?? - Szydłówek (Dominiak \& Moćko 1980); 24. EE7422?? - Zagórze (Dominiak \& Moćko 1980); 25. EE8201 - NE of the NW edge of Milechowy v. (SW slope of Grzaby Bolmińskie range), 5049'33.5"N; 20¹9'54.0" E; 26. EE8202 - NE of the central part of Bolmin v. (SW slope of Grząby Bolmińskie range), 5048'59.4"N, 20²1'05.9"E; Bolmin (Dominiak \& Moćko 1980); 27. EE8223 - n. Choiny v. (Bróż \& Przemyski 1992 not publ.); 28. EE8303 - Nowiny (Bróż 1991 not publ.); 29. EE8310 - Korzecko (Dominiak \& Moćko 1980); 30. EE8400 - N of Kowala Duża (Bróż \& Maciejczak 1991 ); 31. EE8410 - S of Kowala Duża (Bróż \& Maciejczak 1991); Wzgórza Kowalskie - Kowala Duża, 5. 1988, leg. E. Bróż \& A. Skrzypczak (KTC ); NN: 32. DF1913 - Mstyczów? (Głazek et al. 1986-1987; Nobis et al. 2007); 33. DF2913 - at the foot of Biała Góra Mt. n. Tunel, 6.1969, leg. H. Błaszczyk (KRA 89667); Biała Góra Mt. above Uniejów-Rędziny v., 2.07.1947, leg. J. Kornaś (Herbarium of A. \& J. Kornaś); Uniejów-Rędziny n. Tunel, 14.09.1948, leg. J. Kornaś (KRA 72777); Tunel n. Miechów, 8.06.1952, leg. H. Błaszczyk (KRA 054143) \& 22.06 .1952 leg. H. Błaszczyk (KRAM 185153, 490628) \& leg. E. Pancer (KRAM 225982); Piaskowiec Mt. n. Tunel, W slope above Uniejów Księży v., 25.05.1947, leg. B. Pawłowski (KRAM 325035) \& 25.05.1947, leg. J. Kornaś (Herbarium of A. \& J. Kornaś); Uniejów Księży n. Tunel, 30.05.1952, leg. B. Gumińska (KRA 0272584); Uniejów n. railway station in Tunel, 22.06.1947, leg. K. Kostrakiewicz (KRAM 230052); 34. EF0312? - Motkowice, 18.07.1980, leg. W. Więcławik (KRA 0225252); 35. EF0320 - Imielno (Głazek et al. 1986-1987; Nobis et al. 2007; W. Więcławik 1982 not publ.); 36. EF0533 - Zawada (Głazek et al. 1986-1987; Nobis et al. 2007; E. Kowalik 1980 not publ.); 37. EF1302 - at the foot of S slopes of Pińczów Mts, between Skowronno reserve and closed dairy in Pińczów (Nobis et al. 2007); Skowronno (Kostrowicki 1966); Skowronno Dolne n. Pińczów, 24.05.1972, leg. R. Ochyra (KRAM 226748); Skowronno, 30.07.1980, leg. A. Zawłodzka (KRA 0228956); 38. EF1303 - at the foot of S slopes of Pińczów Mts, between Skowronno reserve and closed dairy in Pińczów (Nobis et al. 2007); Pińczów Mts (Głazek 1984; Głazek et al. 1986-1987); 39. EF1313? - Pińczów (Kostrowicki 1966; Głazek et al. 1986-1987); 40. EF1412 - Galów (Głazek et al. 1986-1987; Nobis et al. 2007; A. Piekutowska 1979 not publ.); 41. EF1420 - at the foot of S slopes of Pińczów Mts, E of Pińczów (between Pińczów and Bogucice v.) [Nobis et al. 2007]; 42. EF1421 - at the foot of S slopes of Pińczów Mts, E of Pińczów (between Pińczów and Bogucice v.) [Nobis et al. 2007]; Bogucice, between Pińczów and Busko, 21.05.1920, leg. B. Pawłowski (KRA 118767; KRAM 325037); 6.07.1947, leg. B. Szafran (KRAM 008150); Bogucice (Kostrowicki 1966); 43. EF1433 - Wełcz n. Pińczów, 2.06.1984, leg. M. Piotrowska (KRA 0232957); 44. EF1502? - Młyny (Fijałkowski \& Cieśliński 1975; Szwagrzyk 1987); 45. EF1531 Busko Zdrój (Fijałkowski \& Cieśliński 1975; Szwagrzyk 1987); 46. EF1533? - Żerniki, 7.06.1957, leg. K. Chronowska (KRAM 098512); Żerniki Górne (Głazek et al.1986-1987; Nobis et al.2007; T. Głazek 1983 not publ.); 47. EF2030 - Pstroszyce Podbukowiec (Szwagrzyk 1987; K. Leszczak 1979 not publ.); 48. EF2031 - Strzeżów (Szwagrzyk 1987); 49. EF2302 - Młodzawy (Kostrowicki 1966); 50. EF2400 - n. Krzyżanowice reserve, from the side of the road connecting the v. Gacki and Krzyżanowice (Nobis et al. 2007); Krzyżanowice (Kostrowicki 1966); 51. EF2401 - n. Wola Zagojska Dolna, between narrow gauge railway and the foot of a gypsum hill extending from Skotniki Górne v. to the Dolina Nidy plant (Nobis et al. 2007); 52. EF2412 - n. Wola Zagojska Dolna, between narrow gauge railway and the foot of a gypsum hill extending from Skotniki Górne v. to the Dolina Nidy plant (Nobis et al. 2007); Winiary n. Busko, 6.06.1953, leg. A. Jasiewicz (KRAM 421543); Skotniki Górne (Głazek et al. 1986-1987; Nobis et al. 2007); 53. EF2413 - Skorocice n. Busko Zdrój 6.06.1953, leg. A. Jasiewicz (KRAM 421542); 3.06.1966, leg. K. Szczepanek (KRA 111536); 19.05.1971, leg. R. Ochyra (KRAM 226747); 30.05.1984, leg. A. Mirosławska (KRA 0228353); Skorocice (Szwagrzyk 1987; A. Mirosławska 1985 not publ.); 54. EF2421 - Zagość (Kostrowicki 1966$) ; 55$. EF2502 - between Busko and Owczary, 26.05.1951, leg. A. \& J. Kornaś (KRA 054145); 56. EF3123? - Racławice? (Głazek et al. 1986-1987; Nobis et al. 2007); 57. EF3400 - Pełczyska-Złota (Głazek et al. 1986-1987; Nobis et al. 2007); 8.1976, leg. ? (KRA 0228771); 58. EF5402 - Przemyków (Głazek et al. 1986-1987; Nobis et al. 2007); 7.07.1982, leg. E. Trela (KRA 0236374); 59. EF5411 - Sokołowice-Siedliska? (Głazek et al. 1986-1987; Nobis et al. 2007); OB: 60. DE7531 - Kłobukowice (Wnuk 1981); 61. DF2802 - Kleszczowa (Wnuk 1981). 